\title{
COLLABORATIVE PLANNING, FORECASTING, AND REPLENISHMENT IMPLEMENTATION: A CASE STUDY OF A MAJOR GROCERY RETAILER IN SOUTH AFRICA
}

\author{
W. Niemann ${ }^{1 *}$, T. Kotzé ${ }^{1} \&$ D. Jacobs ${ }^{1}$
}

\section{ARTICLE INFO}

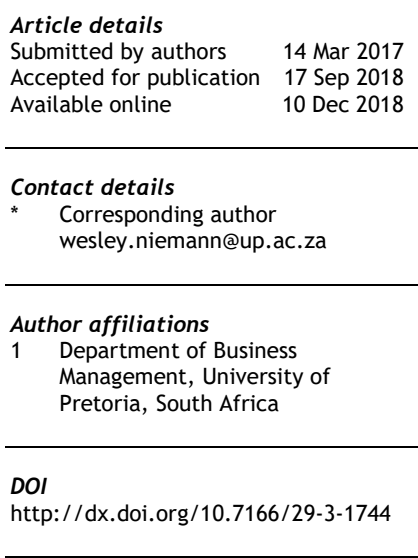

The purpose of this study was to investigate the key factors that affect the implementation of collaborative planning, forecasting, and replenishment (CPFR). A single case study method was adopted, examining a critical case in the South African grocery retail sector. Semi-structured interviews were conducted to collect data. The study confirmed five of the six key factors affecting CPFR implementation that have been identified in the literature. Two new key factors, business understanding and a common goal, were identified. The study also determined the framework that the focal firm used to implement CPFR. The findings aid supply chain managers in understanding and leveraging the key factors that affect the successful implementation of CPFR. The framework can be used for benchmarking and guiding managers through the process of implementing CPFR.

\section{OPSOMMING}

Die doel van hierdie studie was om die belangrike faktore wat die implementering van gesamentlike beplanning, vooruitskatting, en aanvulling (GBVA) beinvloed te ondersoek. 'n Enkele gevallestudie metode was gebruik om 'n kritieke geval binne die Suid-Afrikaanse kruideniersware kleinhandelsektor te ondersoek. Semigestruktureerde onderhoude was uitgevoer om data in te samel. Die studie het vyf van die ses belangrikste faktore bevestig wat GBVA implementering beïnvloed, soos wat vervat is in die literatuur. Twee nuwe sleutel faktore, besigheidsbegrip en 'n gemeenskaplike doel, was geïdentifiseer. Die studie het ook die raamwerk bepaal wat die firma gebruik het om GBVA te implementeer. Die studie bemagtig voorsieningskettingbestuurders om die belangrikste faktore wat die suksesvolle implementering van GBVA beïnvloed te verstaan en te benut. Die raamwerk kan help om ' $n$ normtoets te stel en bestuurders te lei deur die proses van die GBVA implementering.

\section{INTRODUCTION}

The benefits of collaborative planning, forecasting, and replenishment (CPFR) for grocery retailers have been described as 'ground breaking'; but what good are such cost-saving, lead time-reducing and sales-increasing concepts if they cannot be implemented successfully [1-4]? CPFR is described as "collaboration where two or more parties in the supply chain jointly plan a number of promotional activities and work out synchronised forecasts, on the basis of which production and replenishment are determined" $[5,6]$.

Several studies have demonstrated the improvements in supply chain performance due to CFPR [3, 7-9]. Despite the convincing results of CPFR, its implementation rate is far lower than anticipated $[10,11]$. It is widely accepted that collaboration in any industry is potentially a way of attaining a competitive advantage $[12,13]$. More recently, the term 'collaborative advantage' has been used 
to describe the result of a competitive advantage directly attributable to collaboration among partnering entities in an industry [14]. One possible way to overcome the challenges of overstocking, understocking, missed sales, and expired stock that grocery retailers face is to integrate their supply chain with that of their suppliers. The widely known and much-suggested framework to accommodate this idea is known as collaborative planning, forecasting, and replenishment [15].

CPFR was originally coined by an international organisation, Voluntary Inter-Industry Commerce Standards (VICS), when it was registered as a trademark in 1998 [16]. The purpose of CPFR was to reduce inventory levels and improve customer service. In 1998, Wal-Mart and Warner-Lambert pioneered the introduction of CPFR, and focused on Listerine products, resulting in a drastic reduction of inventory levels and increased sales [15]. That was the starting point for Wal-Mart to undertake this initiative with several key suppliers. Wal-Mart is currently the largest retailer in the United States [17]. Despite the highly-accredited and beneficial framework of CPFR set out by VICS, its full benefits are often not realised due to its complex nature $[10,13,18]$. Only a few partnering firms, such as Wal-Mart and Warner-Lambert, have been able to reap the full benefits of CPFR [11]. Greater attention should, therefore, be given to the collaborative initiative of CPFR.

One of the key explanations for the failure to implement CPFR successfully is the lack of detailed and comprehensive guidelines about the key factors and the implementation framework [19]. In the global context, few studies have explored the issue of the key factors affecting CPFR implementation $[20,21]$. In the South African context, few studies on CPFR implementation exist, which leaves a lack of consensus about its key factors or implementation framework [2]. This confirms that this topic is still to be fully understood. These two issues are evident partly from a global perspective, but more specifically from a South African perspective.

The purpose of this study was twofold. First it explored the key factors faced by supply chain members in implementing effective CPFR in the South African grocery retail environment; and second, it identified the framework that is used by a major grocery retailer in South Africa. This study involved a qualitative case study of one of the four largest grocery retailers in South Africa.

The following research questions were addressed in this study:

- What are the key factors affecting CPFR implementation for a major grocery retailer in South Africa?

- What framework does the major grocery retailer use to implement CPFR?

This study aimed to be academically valuable in order to contribute to an understanding of the key factors that affect the implementation process of CPFR. The stakeholders that can benefit from this study are academics, supply chain practitioners, and retail firms. A greater understanding of these factors can result in improvements to CPFR implementation projects by focusing on and leveraging those key factors. This study provides an in-depth understanding of the key factors affecting the process of implementing CPFR, considering the challenges faced in a South African context. The findings of the study benefit the above-mentioned stakeholders in several ways. First, the study benefits academics by expanding on the limited literature available on the key factors of CPFR implementation by confirming five of the six key factors, and adding two additional key factors. Second, the study benefits supply chain practitioners by exploring (from a practice-led perspective) the key factors of CPFR implementation of a major South African grocery retailer to allow for a greater understanding of the implementation process and to improve the implementation efficiency of CPFR. Third, the study adds to the literature on the frameworks used to guide CPFR implementation by recognising a unique framework that is used by a major grocery retailer in South Africa.

\section{LITERATURE REVIEW}

Aligning supply with demand in a timely manner is a longstanding challenge that has improved over time [2, 22, 23]. Yet relevant stakeholders are still not satisfied with the state of supply and demand alignment [2, 22, 23]. In the case of grocery retailers around the world, this challenge is particularly relevant. The issue of reducing inventory levels, improving lead times, accurately forecasting consumer expenditure, appropriately planning for these forecasts, delivering on time in the correct 
quantity, keeping shelves full, and managing exceptional demand through promotional events are just a few of the challenges that are still not completely overcome $[19,24]$. The literature review explores the fundamentals of supply chain collaboration, followed by the benefits of CPFR for firms. It then explores the various frameworks for implementation, followed by the key factors affecting CPFR implementation.

\subsection{Collaboration in the supply chain}

Collaboration occurs in a supply chain "when two or more independent firms work jointly to plan and execute supply chain operations with greater success than when acting in isolation" $[2,11,15]$. The notion of collaboration is attached to the concept of synergy and its development, which encourages joint planning and real-time exchange of information [25]. Various approaches to collaboration in the supply chain exist, such as vendor-managed inventory (VMI), CPFR, and consumer response (CR). This study specifically focused on CPFR due to its beneficial potential that has proven difficult to implement successfully and, therefore, its full benefits have not always been realised $[10,13,18]$.

Collaboration between firms should only be implemented if both entities are willing and capable of investing time and effort, and if the projected benefits are greater than can be achieved individually $[7,24]$. Considering that collaboration is now understood as one of the best ways to increase the likelihood of achieving an enduring competitive advantage, firms should pay attention to collaborative implementation guidelines to establish and manage efficient collaborative relationships. Figure 1 below illustrates the steps involved in developing collaborative relationships between firms.

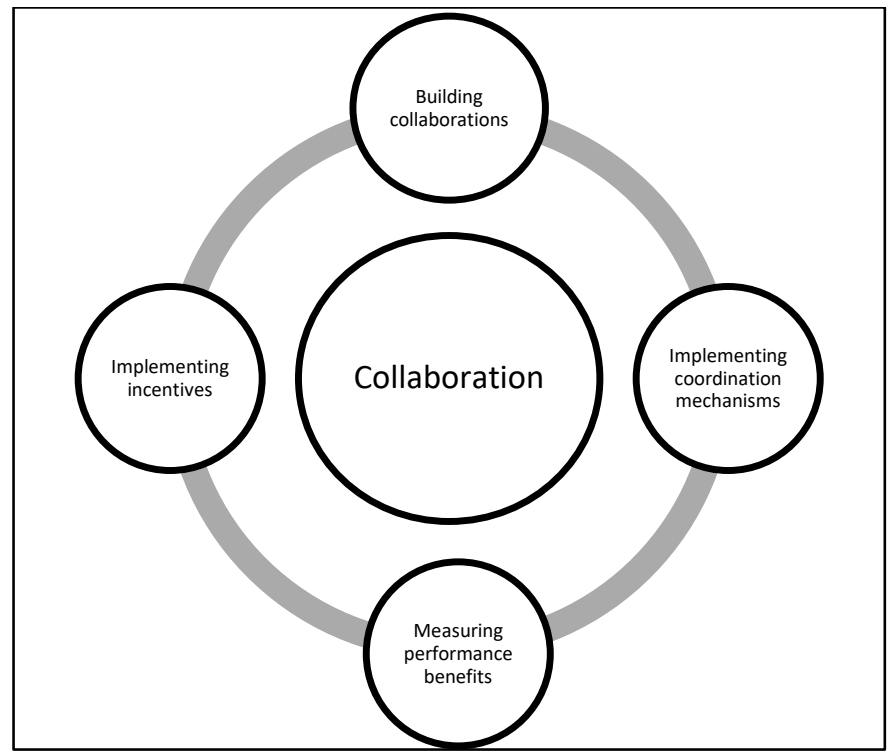

Figure 1: Steps to follow in creating collaborative relationships between firms [24]

According to Lehoux, D'Amours and Langevin [24], the starting point in the four main aspects of creating collaboration is building collaboration. This involves the selection of partners, developing a legal framework, and managing relationships and their adjustments. The second aspect entails implementing coordination mechanisms for information-sharing and swift negotiation processes. The third aspect focuses on measuring performance and benefits, which entails the general assessment of collaborative efforts and whether these efforts are sustainable and worth the effort for collaborating members. The fourth aspect highlights the implementation of incentives - their selection and alignment.

\subsection{The development of collaborative planning, forecasting, and replenishment}

Recently the focus has increasingly been on collaboration in supply chains as a process that improves all-round cooperation among firms [26]. During the early 1990s, efficient consumer response (ECR) 
developed as a powerful collaborative initiative that arose in the grocery and consumer packaged goods (CPG) industries [25, 27]. ECR promotes the idea of sharing strategic information and developing relationships based on trust in order to seek improvements in supply chains, ultimately to create a greater level of customer value [25]. It was considered to be the starting point for some additional collaborative approaches, which included continuous replenishment (CR), vendormanaged inventory, and CPFR. These collaborative approaches all aim to develop and improve the level of supply chain integration through the notion of information-sharing. According to VICS [16], CPFR is "a collection of new business practices that leverage the Internet and Electronic Data Interchange (EDI) in order to radically reduce inventories and expenses while improving customer service". Danese [28] defines CPFR as a programme that seeks to improve the ability to anticipate and satisfy future demand by enhancing collaboration among firms in the supply network. CPFR is considered to be the most promising of these collaborative approaches, because it provides a thorough examination of factors that can create uncertainty, such as promotional activities. Beyond that, CPFR also focuses on delivering a greater level of coordination among retailers and manufacturers [29]. With the development of ECR, the supply chain members, retailers, and manufacturers started to develop collective solutions to the uncertain supply chain environments in which they were operating.

\subsection{Benefits of collaborative planning, forecasting, and replenishment}

By connecting marketing and sales efforts to supply chains, CPFR enables trading partners to improve the visibility of their critical activities using a structured framework and a process of informationsharing and joint decision-making across organisational level boundaries [13]. In the context of supply chain management, mutual advantages are often construed as a positive return on investments and an increased efficiency in inventory management [24, 30]. For instance, Wal-Mart collaborated with Warner-Lambert in the hope of attaining mutual benefits from their CPFR initiative. The mutual benefits came in the form of improving the stock levels of Listerine from 87 to 98 per cent; lead times were essentially halved from 21 to 11 days; inventory on hand was reduced by two weeks; sales improved by 8.5 million dollars; and orders became more consistent. Aiming for a similar return, General Electric (GE) made an effort to collaborate with its retailers to respond efficiently to consumer demand rather than to inventory [31, 32]. GE focused on a build-to-ordersystem: both members of the supply chain eliminated the expense of holding inventory and the assembly of full truckload orders. As a result, GE ultimately reduced its marketing and distribution costs by 12 per cent. The retailers also experienced fewer out-of-stock situations, and increased their profit margins on products from GE.

\subsection{Frameworks of collaborative planning, forecasting, and replenishment implementation}

As mentioned previously, the original and most widely known framework for CPFR implementation is the model introduced by VICS. Several studies have explored the VICS framework or have developed a variation on the VICS framework that entails the detailed processes of CPFR implementation in an attempt to improve the frameworks set out by a number of researchers and practitioners [16, 33-36].

Table 1 depicts the disparities between existing frameworks for CPFR implementation that add to the lack of consensus.

The different frameworks vary in the number of steps, yet all start the process by developing a front-end agreement that sets out the rules of engagement, followed by the joint business plan (JBP). Fliedner [35] describes four simple steps in the framework; the first three steps involve working collaboratively with the retailer and supplier. VICS [16] describes the front-end agreement and JBP to be a part of the same step. They then go on to plan the forecasts between the supplier and retailer, which is done collaboratively, followed by generating the orders and executing them. They end the framework with the very important step of analysing the exception and overall performance, which is vital for improving on the next exception. This step is not specifically included in any of the other frameworks mentioned in Table 1 above. Chang et al. [33] separate the frontend agreement and joint business plan into two different steps. They then forecast the regular sales and identify the unusual sales forecasts, which is done separately by the retailer and the supplier. The supplier and retailer meet to deal collaboratively with those unusual sales forecasts. The next step is to forecast the orders and identify unusual order forecasts. The supplier and retailer then deal collaboratively with those unusual order forecasts and, finally, generate and execute the 
orders. Fliedner [35] and VICS [16] depict collaborative work occurring throughout the framework, while Chang et al. [33] describe step 5 and step 8 to be specific collaborative steps in the framework. Du et al. [34] simplify the framework into three steps. The first step involves the development of a front-end agreement and JBP. The next step involves the collaborative efforts of the retailer and supplier generating sales and order forecasts. The last step is to generate the orders and execute the shipments. Shu et al. [36] divide the steps in the framework into three categories: planning, forecasting, and replenishment. This framework also sets out specific steps in which the retailer and supplier would forecast sales and orders separately, and then resolve them collaboratively.

Table 1: Frameworks for CPFR implementation (Source: Adapted from Hollmann et al. [3])

\begin{tabular}{|c|c|}
\hline Fliedner [35] & $\begin{array}{ll}\text { 1. } & \text { Create a front-end agreement } \\
\text { 2. } & \text { Create a joint business plan } \\
\text { 3. } & \text { Develop forecasts } \\
\text { 4. } & \text { Replenish inventory }\end{array}$ \\
\hline VICS [16] & $\begin{array}{l}\text { 1. } \quad \text { Strategy and planning: an arrangement and joint business plan } \\
\text { 2. } \quad \text { Demand and supply management: sales forecasting and order planning/forecasting } \\
\text { 3. Execution: order generation and order fulfilment } \\
\text { 4. }\end{array}$ \\
\hline $\begin{array}{c}\text { Chang et al. } \\
\text { [33] }\end{array}$ & $\begin{array}{l}\text { Based on the framework of VICS [16], but includes the process of an application service that } \\
\text { uses market information to improve forecast accuracy: } \\
\text { 1. Formulate a draft agreement } \\
\text { 2. Develop a joint business plan } \\
\text { 3. Forecast sales } \\
\text { 4. Identify unusual sales forecasts } \\
\text { 5. Deal collaboratively with unusual items } \\
\text { 6. Forecast orders } \\
\text { 7. Identify unusual order forecasts } \\
\text { 8. Deal collaboratively with unusual items } \\
\text { 9. Generate orders }\end{array}$ \\
\hline $\begin{array}{c}\text { Du et al. } \\
\text { [34] }\end{array}$ & $\begin{array}{l}\text { Based on VICS [16] framework, but reorganises the framework into three steps: } \\
\text { 1. Development of a collaborative agreement and preparation of a joint business plan } \\
\text { 2. Generation of collaborative sales and order forecasts } \\
\text { 3. Generation of orders and execution of shipments }\end{array}$ \\
\hline $\begin{array}{c}\text { Shu et al. } \\
\text { [36] }\end{array}$ & $\begin{array}{l}\text { Based on VICS [16], but reorganises the framework to include three processes and eleven } \\
\text { steps: } \\
\text { Planning: } \\
\text { 1. Decompose and search for a module } \\
\text { 2. Reach a forward collaboration agreement } \\
\text { 3. Create a collaboration plan } \\
\text { Forecast: } \\
\text { 1. Forecast sales } \\
\text { 2. Confirm exceptions in sales forecasts } \\
\text { 3. Resolve exceptions in sales forecasts } \\
\text { 4. Forecast orders } \\
\text { 5. Confirm exceptions in order forecasts } \\
\text { 6. Resolve exceptions in order forecasts } \\
\text { Replenishment: } \\
\text { 1. Create orders } \\
\text { 2. Produce and service }\end{array}$ \\
\hline
\end{tabular}

\subsection{Key factors affecting collaborative planning, forecasting, and replenishment implementation}

It is argued that many critical factors to CPFR implementation are both inhibitors and enablers [37, 38]. By placing the phrase 'lack of' in front of a key factor (such as trust), the key factor is placed in an inhibiting light; yet trust is recognised as a key enabler, and thus the term 'key factors' was developed. Several key factors enable or restrain firms from implementing CPFR successfully and completely. It is, therefore, crucial that firms understand these key factors before embarking on collaborative supply chain initiatives such as CPFR. The failure of CPFR to be implemented successfully on an international scale can largely be attributed to a lack of understanding of the key factors faced during the CPFR implementation process $[8,19,20,21,29,39,40]$. By comprehensively reviewing the existing literature, it was found that six key factors are currently recognised $[8,19$, $20,21,29,39,40]$. As many firms suffer from scarce resources, the identification of the most significant factors enables managers to engage with those aspects that are most important in 
successfully implementing CPFR. The next section describes the most widely recognised key factors that affect the implementation of CPFR.

\subsubsection{Technical expertise}

Technical expertise - internally and externally - is a key factor that affects CPFR implementation $[19,35]$. CPFR is complex, and a full-scale implementation in a single stage can frequently lead to disorganisation and frustration in both management and the other participants [19, 35]. Similarly, the implementation of small-scale CPFR projects can primarily induce the growth of technical expertise. This technical expertise can be found internally, but if not available internally, then supply chain consulting groups can be the focal point. An important aspect is to transfer technical expertise to internal employees, who may provide the skills to undertake future CPFR or general collaborative supply chain initiatives.

\subsubsection{Visible and effective leadership}

Visible and effective leadership is a highly important key factor in CPFR implementation [19, 20, 39]. Due to its complex nature, it requires senior leadership's full attention to plan and implement the concept [19, 20,39]. Enhancing this leadership by practitioners, beginning with small-scale CPFR projects and allowing those projects to grow to full-scale projects over time [19], is a potential solution to this factor as an inhibitor.

\subsubsection{Information-sharing}

A significant factor in CPFR implementation is sharing credible information [8, 19, 20, 40]. This issue is noted as being multi-dimensional in nature, which can be amplified by behavioural, technical, and cultural issues. Related to the aspect of information are several factors such as visibility of inventory levels and retail strategies; readiness and timeliness of relevant information for supply chain partners to use; availability and compatibility of information to users; and the security of sensitive information that is supposed to be kept from competitors [21, 25, 41, 42]. The plans of a CPFR implementation venture should define and clearly spell out issues of confidentiality and specify what information will be shared.

\subsubsection{Trust}

The factor of partner trust is crucial in CPFR implementation [20, 21, 29]. Trust can only be developed over time, but can be supplemented by a CPFR charter of specifics that spells out the plans and expectations for CPFR ventures. The ability to create high levels of trust can be dependent on collaborating supply chain members ensuring that promises are met and relevant information is accurate and timely.

\subsubsection{Forecasting processes and resources}

Another key factor is forecasting processes and resources, because forecasting is a fundamental part of CPFR [19, 35]. To assist in leveraging this key factor, trading partners can develop protocols for forecasting, and select a forecasting team with representatives from all the trading partners and stakeholders [19]. The connection of information channels to multiple trading partners in real time also helps to leverage this factor.

\subsubsection{Calculating the benefits}

Another factor in CPFR implementation is the difficulty of calculating the benefits [19]. Fu et al. [20] support this view, stating that perceived benefits are a key factor in CPFR implementation. Despite the potential results mentioned in the literature, these results can only be attained once all the correct preparations have been made. From a firm's viewpoint, it is vital to align internal activities prior to engaging in CPFR with other parties [19].

The next section details the methodological choices.

\section{METHODOLOGY}

\subsection{Research design}

This study employed a single case study design, which is used to study a research problem by reviewing one or more cases in a particular context [43]. Yin [44] emphasises that cases should be current and studied in a real-life context. Case study research uses different sources of information, often producing very descriptive findings, as it focuses on 'how' or 'why' a specific problem occurs [45]. This approach was selected because the purpose of the study was to understand the key factors 
that affect CPFR implementation in a focal firm, as opposed to a random selection of retailers and suppliers.

\subsection{Sampling}

The unit of analysis for this study was the processes used to implement CPFR. This study was conducted on a major South African grocery retailer with divisional headquarters in Gauteng. A purposive sampling strategy - homogeneous sampling - was used to identify major grocery retailers in South Africa. In this instance, the focal firm was selected based on accessibility and because, as one of the four major grocery retailers in South Africa, the focal firm represents a critical case. Subsequently, snowball sampling was used to identify specific individuals in the firm who were senior managers and who were most involved in planning, forecasting, and replenishment. The sample was further refined by selecting employees who were also the most involved in managing suppliers. This was done by asking each of the participants after their interview to recommend a specific colleague, according to the above criteria [46, 47]. Table 4 below presents a summary of the participants in this study.

Table 2: Summary of participants

\begin{tabular}{|c|l|c|c|}
\hline Pseudonym & Position & Firm & $\begin{array}{l}\text { Duration of interview } \\
\text { (in minutes) }\end{array}$ \\
\hline P1 & Divisional logistics director & C1 & 40 \\
\hline P2 & Divisional marketing director & C1 & 37 \\
\hline P3 & Group supply chain project manager & C1 & 38 \\
\hline P4 & Procurement manager - fresh foods & C1 & 34 \\
\hline P5 & Procurement manager - dry foods & C1 & 48 \\
\hline P6 & $\begin{array}{l}\text { National procurement manager - fresh } \\
\text { foods }\end{array}$ & 66 \\
\hline Average interview time in minutes & 44 \\
\hline \multicolumn{2}{|l}{} & 6 \\
\hline \multicolumn{2}{|l}{ Male participants number participants } & 5 \\
\hline Female participants & 1 \\
\hline
\end{tabular}

\subsection{Data collection}

The main source of data was the six semi-structured individual interviews conducted with the research participants. Guest, Bunce and Johnson [48] suggest that, for studies with high levels of homogeneity among the population, a sample of six interviews may be sufficient to enable development of meaningful themes and useful interpretations. Face-to-face interviews were organised because the researcher wanted to understand and make sense of the attitudes, behaviours, and practices of people and firms. Based on the initial literature review, an interview guide was developed that allowed for comparability of answers and improved the reliability of the study [44, 45]. The interviews followed a standard path, organised under broadly defined topics centred on CPFR implementation. Open-ended questions and probing phrases were used to encourage detailed responses. Each interview began with general introductory questions about the background and role of the participant. Subsequently, questions were asked that focused on CPFR, its enablers, inhibitors, and processes for implementation. Questions were adapted, either by changing the order of questions or changing the questions themselves, depending on the direction the interview was taking [49]. In one instance, where the researcher was unable to record one of the interviews, detailed notes were taken throughout the course of the interview. All interviews, except for the aforementioned one, were transcribed by the researcher within 24 hours, following the guidelines stipulated by Eisenhardt [50]. Validation of the transcribed interviews was offered to the participants after each interview to request feedback, clarification, comments, or final approval [44]. The recordings were played again to compare them with the transcriptions, and corrections were made to ensure the transcriptions were verbatim. A pilot study was conducted to test the quality of the questions in the discussion guide. Positive feedback was received, and no major changes were made.

Triangulation was achieved by adding information that was gathered from informal conversations with the participants, reviewing website information online, and making several site visits to the focal firm [51, 52]. This data was used to confirm statements obtained from the interviews, while additional background data was obtained to fill in missing information. 


\subsection{Data analysis}

A thematic analysis approach was used to analyse the data in this study. This is a process in which data is analysed across a data set in order methodically to identify, organise, and understand emerging themes in the set of data [53]. The process applied to the set of data was proposed by Braun and Clarke [53]. First, the researcher became familiar with the data, followed by the generation of the initial codes. The next step involved searching for themes among the codes, which were subsequently reviewed. The reviewed themes were then named and defined, which allowed for the final report to be produced.

\subsection{Trustworthiness}

To ensure the transferability and authenticity of this study, a rich and thick description of the participants, the methodology, the sites, and the context of the study was carried out [54, 55]. Peer debriefing was also applied to address any trustworthiness issues. This meant that the study was investigated by an objective third party to address any trustworthiness issues. An experienced supply chain management academic and a methodology expert were consulted to address any reliability issues that needed correction [55].

To ensure the internal credibility of the study, a thorough review of the existing data and frameworks was done to relate the data to the existing literature [54]. Given the sensitivity of the information provided, due to the competitive environment in which major grocery retailers operate, measures were taken to ensure honesty in the responses provided by the participants. The interviews, therefore, were conducted individually. The researcher stated during each interview that the information shared would be treated confidentially. Rapport was established with each of the participants at the beginning of the interviews. Participants were allowed to withdraw from their interview at any time [54].

\subsection{Ethical considerations}

In order to comply with the ethical principle of informed consent, all of the participants were required to read and sign the informed consent form. This form explained to the participants the purpose of the study, and informed them that participation was voluntary and that they could withdraw at any time during the interview. The assurance of anonymity and confidentiality was also provided in the informed consent form. The same information was communicated verbally to each of the participants before the researcher began the interviews. The names of the participants and firms were replaced with pseudonyms to protect the identity of the participants and to ensure honest responses. The study received ethical clearance from the relevant research ethics committee at a South African university.

\section{FINDINGS}

This study identified the main themes and sub-themes for the implementation of collaborative planning, forecasting, and replenishment at a major grocery retailer in South Africa. In the sections that follow, each of the themes is defined, and the main findings are presented with links to the appropriate literature. The first section presents the findings related to participants' perspectives on the key factors affecting CPFR implementation. The second section presents the findings related to the focal firm's CPFR implementation framework.

\subsection{Key factors affecting collaborative planning, forecasting, and replenishment implementation}

Figure 2 below shows the key factors that were identified in this study. These factors are placed in order of importance, based on the frequencies shown in Table 3.

All six participants mentioned communication as a key factor affecting CPFR implementation. Business understanding, a common goal, and mutual benefit were each mentioned by five of the six participants, while transparency and trust were identified as key factors by four of the six participants. 


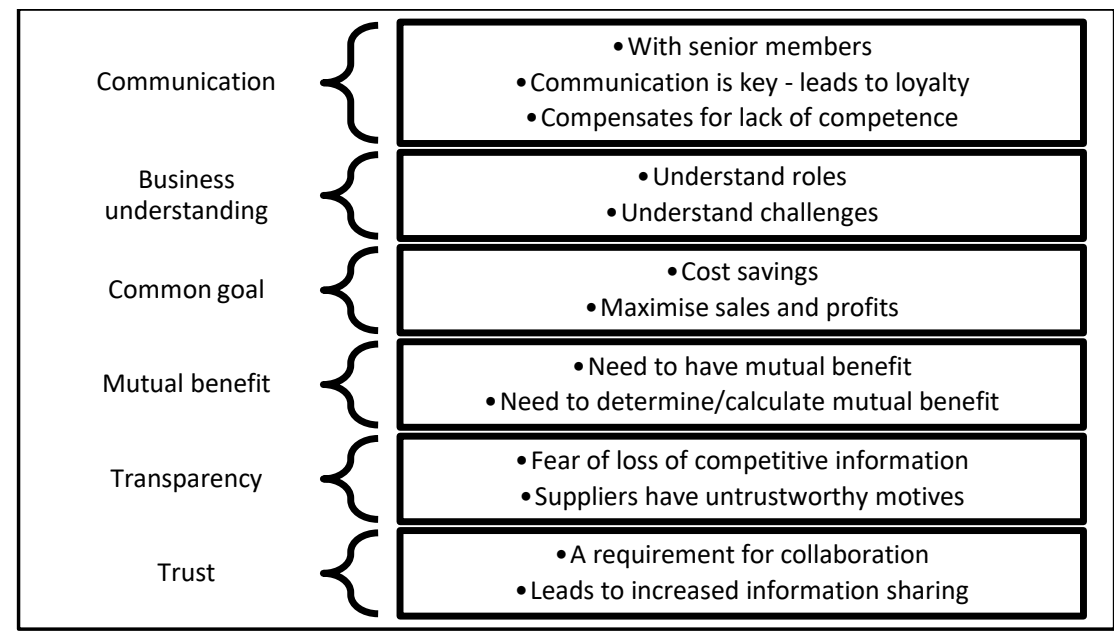

Figure 2: Key factors affecting collaborative planning, forecasting, and replenishmentimplementation

Table 3: Data frequency per participant

\begin{tabular}{|c|c|c|c|c|c|c|c|}
\hline Code & P1 & P2 & P3 & P4 & P5 & P6 & Total frequency \\
\hline Communication & $\mathrm{x}$ & $x$ & $\mathrm{x}$ & $x$ & $\mathrm{x}$ & $x$ & 6 \\
\hline Business understanding & $x$ & $x$ & $\mathrm{x}$ & $x$ & & $\mathrm{x}$ & 5 \\
\hline Collaboration importance & $x$ & $x$ & $\mathrm{x}$ & & $x$ & $x$ & 5 \\
\hline Common goal & $\mathrm{x}$ & $x$ & $\mathrm{x}$ & & $x$ & $x$ & 5 \\
\hline Mutual benefit & $\mathrm{x}$ & $x$ & $\mathrm{x}$ & & $x$ & $\mathrm{x}$ & 5 \\
\hline Promotional planning & & $\mathrm{x}$ & $x$ & $x$ & $x$ & $x$ & 5 \\
\hline Transparency & & $x$ & $x$ & $x$ & $x$ & & 4 \\
\hline Trust & & $\mathrm{x}$ & $\mathrm{x}$ & $x$ & $x$ & & 4 \\
\hline Flexibility & & & $\mathrm{x}$ & & $x$ & $x$ & 3 \\
\hline Systems integration & & $x$ & & $x$ & $x$ & & 3 \\
\hline Focus on transport logistics & & $\mathrm{x}$ & $\mathrm{x}$ & $x$ & & & 3 \\
\hline Informal & & & & $x$ & $x$ & $x$ & 3 \\
\hline Competence & & & & $x$ & & $x$ & 2 \\
\hline Resources & & $\mathrm{x}$ & & & & $x$ & 2 \\
\hline Interpersonal relationships & & & $\mathrm{x}$ & & & $x$ & 2 \\
\hline Commitment & & $\mathrm{x}$ & & & & $\mathrm{x}$ & 2 \\
\hline Focus on big suppliers & & $x$ & & $\mathrm{x}$ & & & 2 \\
\hline Perishable volatility & & & & $\mathrm{x}$ & & $x$ & 2 \\
\hline
\end{tabular}

The section below discusses the eight key factors affecting CPFR implementation, and includes the use of participant quotes.

\subsubsection{Communication}

Communication is defined as information sharing and, if done effectively and efficiently, supply chain relationships can be maintained successfully [56]. All of the participants highlighted communication as a key factor involved in successful collaborative ventures. The participants maintained that communication can contribute to building successful relationships, but ineffective communication can also be a powerful tool in breaking these relationships down. It was noted that communication with senior members in the partnering firm is crucial to implementing effective plans. It was also noted that communication can supplement the lack of competence, and that effective communication in advance can lead to loyalty:

"I think communication is key... it's better for them to advise the trade and prepare the trade than unexpectedly just being out of stock. Because then it causes a lot of relationship breakdowns, a lot of mistrust ... a lot of that collaboration goes out the window" (P2, male, divisional marketing director) 
This is confirmed in the literature review by references to information-sharing as a valuable communication tool $[8,19,20,40]$. Despite the acknowledgement by each of the participants that communication is a crucial factor, a number of the participants suggested that there is a lack of communication.

“... so often we don't communicate enough ... what is that that I want to achieve; what is the overall objective; who are the key stakeholders we need to involve and how do I communicate with them; how do I get them involved in this exercise?" (P2, male, divisional marketing director)

\subsubsection{Business understanding}

Understanding is defined as the point when two or more people share the same knowledge and clarity on a specific subject - in this context specifically, the domain of business [57]. A number of the participants mentioned this as not only beneficial to the supply chain but, more importantly, the business as a whole:

"I think an understanding of each other's businesses. I think this is key because I must understand the challenges facing manufacturing in the supply chain and likewise they must understand my challenges ... find that common ground going forward" (P2, male, divisional marketing director)

"... who do we believe would be the most meaningful to collaborate with to have an understanding of how that business operates and no different to them understanding what your business is about and how you operate, so that's part of it. Supply chain is basically an element to that." (P3, male, group supply chain projects manager)

This finding is not evident in the literature as a key factor affecting CPFR implementation.

\subsubsection{Common goal}

A common goal exists when two or more people from a work group share the same target to be achieved [58]. Five of the six participants suggested that a common goal should be the starting point and a major driver for a potential collaborative venture such as CPFR. The most frequent common goals mentioned were to reduce costs or increase sales:

"...there's a whole lot of reasons for the various departments or firms or partners that work together with joint ventures instead of just working in silos because together with we can strip out costs, together we can actually drive our business forward." (P2, male, divisional marketing director)

"It's vital, I think in this environment you always trying to stretch the profit and maximise efficiencies to cut costs to an absolute minimum and the only way to do that is to structure collaborative relationships with your suppliers so that you are able to harness those efficiencies" ( $P 5$, male, procurement manager - dry goods)

This finding is not evident in the literature as a key factor affecting CPFR implementation.

\subsubsection{Mutual benefit}

A mutual benefit exists when a relationship is beneficial to both parties involved [59]. The participants acknowledged the need for both suppliers and retailers to benefit from collaborative ventures, and their ability to determine a mutual benefit as a key factor:

"Critical to determine mutual benefit so there is reason to develop collaborative relationships." (P1. Male, divisional logistics director)

"We've got to enter into the relationship with a win-win attitude. So you know I can't enter into a joint venture with a supplier and want to benefit from all the savings and not want to pass any of that savings on to the manufacturer." (P2, male, divisional marketing director)

This factor was confirmed in the literature review [19, 20].

\subsubsection{Transparency}

Transparency was emphasised by four of the six participants as a key factor that is linked with strategic information used against competitors and suppliers. However, at the moment there is a deliberate lack of transparency; and the participants felt that this strategy should be changed: 
"We don't always want suppliers to know what stock we sitting on because we might want to use it strategically later on, because we know there's a price increase coming and want to be able to drop the price but I think that is short-sighted ... I think that's lacking within our industry because you know we so afraid that $\mathrm{C} 3$ is going to know what we've got and C2 is going to know what we've got and they are probably the same." (P2, male, divisional marketing director)

While transparency was not explicitly named as a key factor affecting CPFR implementation in the literature, it is referred to as 'visibility' under the heading of information-sharing [41].

\subsubsection{Trust}

'Trust' is defined as the confidence one party has in the dependability and honesty of the other party [60]. Fawcett, Jones and Fawcett [61] define 'trust' as the foundation for collaborative alliances. The participants identified trust as a major factor that affects the success of collaborative relationships:

“... so, if I don't trust the supplier then I'm not necessarily going to enter into agreement with them. I'll give you an example ... I think some supplies are notorious for being out of stock before a price increase and then after a price increase, then voila, all of these stocks are available can you sit back and think all two weeks ago, I couldn't get stock because you said that you had capacity constraints in terms of production and suddenly now price increase is taking effect ... I don't want to share my balance on hand with you, I don't want to share my inventory levels with you because I don't trust your motives." (P5, male, procurement manager - dry goods)

Spekman and Carraway [62] found that, if trust is present in a relationship, partners are more likely to invest in relationship-specific assets and share more knowledge and information. This is confirmed by the findings in the literature review $[20,21,29]$.

\subsection{CPFR implementation framework}

Figure 3 below depicts the CPFR implementation framework that is used by the focal firm. The framework was derived using information gathered from the participants during the interviews.

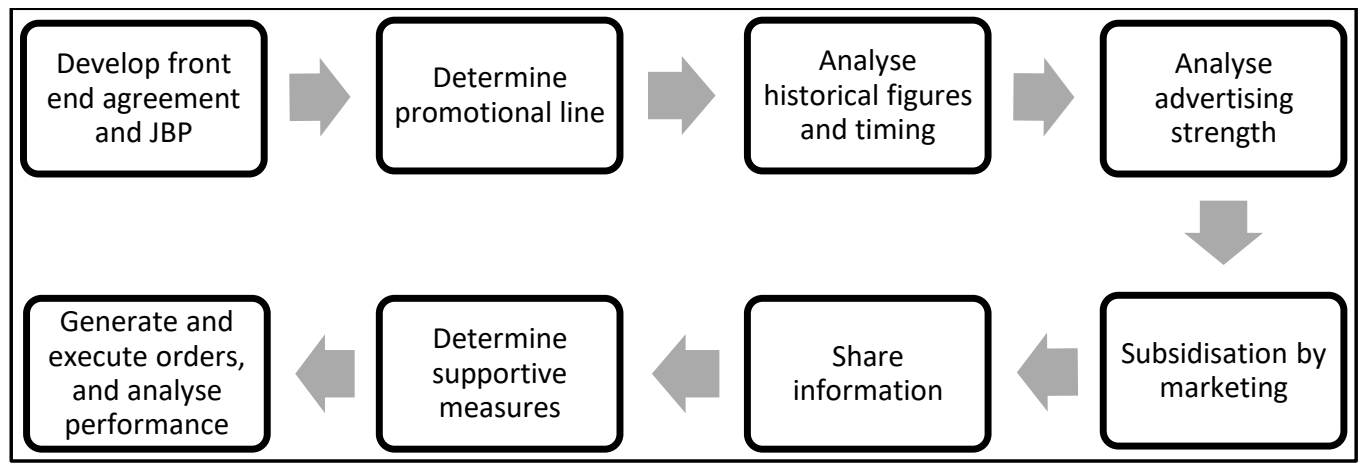

Figure 3: CPFR implementation framework

The discussion below describes Figure 3 and includes the use of participant quotes.

\subsubsection{Rules of engagement}

The first step in the CPFR process is to develop the rules of engagement and JBP. This also includes the aspect of exclusivity. In this context, 'exclusivity' refers to the fact that only one major retailer has a promotion on a certain product or group of products at a particular time:

"Rules of engagement ... supported by honesty transparency and trust ... You've got to agree on what those rules are and ... map them out and what both parties want to get out of it and that's then going to govern that relationship." (P3, male, group supply chain projects manager) 
"... the grids are done in advance so they can also plan ... It doesn't help you being on promotion at $\mathrm{C} 1$ and $\mathrm{C} 2$ and $\mathrm{C} 3$ at the same time because then your volumes are just going to kill you." (P5, male, procurement manager - dry goods)

This step is in alignment with the frameworks described in the literature [16, 33-36].

\subsubsection{Determine promotional line}

This step involves determining the promotional line. This is either provided by the supplier on a 12 month promotional grid specifying what product they intend to promote throughout the year, or it can be decided by the retailer. For instance, P7 stated that they often promote if they have an excess of that product, particularly in the perishables grocery category:

"... we sit with them at the beginning of the year and we set up a promotional grid for the year so they know what months have got specific promotions." (P4, female, procurement manager - fresh foods)

"... we try and in a way drive volume on lines that are freely available." (P6, male, national procurement manager - fresh foods)

This step was not evident in the literature, possibly due to the dynamic environment of constantly changing plans.

\subsubsection{Analyse historical figures and timing}

In this step, both the supplier and the retailer analyse their historical figures on volume bought from the supplier, volume moved through the distribution centre (DC), and volume sold from the store. Aspects of time play a major role, as mentioned in the extract:

"... call that supplier to review that data, sit with them to validate what we've done in the past and look at what some of those key factors are that might drive a change in that offtake ... Is that promotional period like on like ... what time does it fall over, did it fall over long weekend, midmonth, month-end, with the holidays, with school holidays." (P3, male, group supply chain projects manager)

This is confirmed in the literature as generating sales forecasts; but, as P3 describes, this step involves both the retailer and the supplier working collaboratively to confirm or validate the data; and this is most similar to the second forecasting step in the framework set out by Du et al. [34].

\subsubsection{Analyse advertising strength}

This step was not described in the literature but, as this study has shown, the marketing, procurement, and logistics departments are closely interlinked. Thus, once the figures have been analysed, a marketing analysis must be done to determine the advertising strength that will affect the volumes being moved:

“... is it supported by TV, press, radio, regional, national? All of those have a different impact on the amount of volumes you going to move." (P3, male, group supply chain projects manager)

\subsubsection{Subsidisation by marketing}

This is also a factor that would need to be analysed and worked into the planning. This factor would be linked with the last step of the framework by analysing the performance subsequent to the promotion. As P3 mentions, the promotion cannot result only in customers coming to buy the product on promotion; rather, it has to result in new customers developing new habits of shopping at that store:

“... what price is going to be subsidised from marketing the product cost ... you get feet through the door and you just keep on subsidising product and maybe the reciprocal spin off by getting feet through the door isn't the kind of feet you want through the door because all they do is coming to buy your Easter eggs and then not aligning the shopping patterns to the balance of the store." (P3, male, group supply chain projects manager) 


\subsubsection{Share information}

Once both parties have done their analysis of sales forecasts, ordering forecasts, and the variable factors (advertising strength and subsidisation), they will then share the information with the relevant supply chain members, validate the information, and manage it accordingly:

"... you can go back to your manufacturing guys and your distribution guys and say what this is, what the marketing this is what my buying team require, share that with them and share that with the supplier and make sure that there's some validation of what that looks like on prior year." (P3, male, group supply chain projects manager)

\subsubsection{Determine supportive measures}

This step was not evident in the literature, as the supportive measures are more indirect. It was noted that there is a lot of focus on these supportive measures, potentially because CPFR cannot succeed in isolation. In this context, 'isolation' is referred to as the individual departments that are responsible for forecasting and replenishment. Supportive measures are required from several departments, such as the transport logistics department, the seniors in charge of labour on a production line or a distribution centre, potentially the projects manager, etc. This step involves planning and strategy around spatial constraints, labour changes to accommodate extra demand, and logistical tactics (just in time):

“... being able to understand what is the impact of that on space utilisation, on our business, on their business and how many days' inventory am I going to be required to hold. What are the implications on space for both of us and do I need to require extra facilities to do that or do I need a change in my manufacturing side? Do I need to do just in time? What's the hold I'm going to send that products through to that facility or onward to my warehouse and am I going to change and add an additional shift to meet that demand ... am I going to accelerate my production which should take my off-take through the C1 DC to meet the demand?" (P3, male, group supply chain projects manager)

"... with us back at the distribution centre is that all sales history is recorded by us, so we know exactly what stores are ordering on what lines and the frequency and everything else. And we build into our systems, we build capacity for just in time and things like that." ( $P 2$, male, divisional marketing director)

\subsubsection{Generate and execute orders, and analyse performance}

The last step of the process would be to implement the plans and generate the orders, followed by analysis of the performance. This step is most similar to step four (i.e., performance analysis) in the VICS [16] framework:

"... you want to look at the volume and value, that is sales value, sales volume in Rand terms, targets aligned to those across categories within the business division so that the marketing guys should be setting those and reviewing those on a quarterly and annually basis and they should be meeting with you, evaluating those." (P3, male, group supply chain projects manager)

\section{CONCLUSION}

\subsection{Summary of findings and theoretical implications}

The aim of this study was to gain an in-depth understanding of the implementation process of CPFR in a major grocery retailer in South Africa.

The first research question focused on identifying the key factors that affect CPFR implementation in a major grocery retailer in South Africa. In this study, the key factors were identified as communication; business understanding; a common goal; mutual benefit; transparency; and trust. Two factors that the participants felt are crucial to CPFR implementation, business understanding and a common goal, are not evident in the literature. Five of the six participants emphasised the importance of these two key factors. It was noted that it is important for the supply chain members to understand their roles from a business point of view. It was stressed that the success of CPFR implementation is heavily dependent on the supply chain members understanding each other's business. The common goal was duly noted, in that it is required for the firms to work together. This 
common goal was most frequently noted as the drive towards cost savings or increased sales. To this extent, the findings add to the existing body of knowledge, particularly in a South African retail grocery context.

The second research question focused on identifying what framework the focal grocery retailer in South Africa uses for CPFR implementation by. The framework was compiled by making use of the descriptions provided by the participants. The framework derived from the findings is not like any of the frameworks described in the literature. There were three steps that could be linked to some of the frameworks in the literature. The first step that is agreed on by both the literature and the study is the front-end agreement and joint business plan. The second alignment with the literature is the second step in the framework set out by Du et al. [34]. The last alignment is with VICS [16], in analysing the performance. This confirms that there is still a lack of consensus about an implementation framework for CPFR. The findings about the framework add a new holistic dimension to the framework. It was noted that the focal firm focused largely on factors that are indirectly linked to CPFR. This is because CPFR is not a venture that operates in isolation; rather, it requires support from multiple stakeholders in multiple departments on multiple levels of seniority between the retailer and the supplier for its successful implementation. These factors were planning and strategy around spatial constraints, labour changes to accommodate extra demand, logistical tactics such as 'just in time', advertising strength, and subsidisation by marketing. (Subsidisation by marketing is a method that the focal firm uses to bring new customers into the stores, and to shift their buying patterns to remain at that store.) This suggests that CPFR is very much interlinked with the marketing, logistics, and procurement departments, and cannot succeed in isolation.

\subsection{Managerial implications}

The findings contribute to an understanding of the implementation processes of CPFR in a major grocery retailer context in South Africa. Managers often neglect thorough implementation processes - specifically about CPFR - which has often resulted in achieving unsatisfactory results $[10,11]$. By acknowledging, focusing on, and leveraging the key factors described in this study, managers can increase the likelihood of achieving satisfactory results in CPFR implementation.

The framework described can, first, be used in benchmarking projects. Second, it can assist managers by guiding them through CPFR implementation. At each step in this framework, the participants have described various factors for consideration that add to the thought processes of the parties involved. The framework of the focal firm has proven to be unique when compared with other frameworks found in the literature. Supply chain managers can compare it with internationally recognised frameworks to determine the framework that may suit their business best.

From the suppliers' point of view, they gain insight into what is most important from the perspective of retailers. When suppliers acknowledge the viewpoints of retailers, they will be more aware of what is crucial to developing and maintaining collaborative relationships. This will aid in promoting the successful implementation of collaborative initiatives, such as CPFR.

\subsection{Limitations and directions for future research}

The findings of this study contribute to the academic understanding of the process of CPFR implementation. However, the findings stem from only one firm, which may limit their applicability to other firms operating in the same industry. Although the research offers managerial insights into grocery supply chains operating a retail model, the findings could add value to similar studies in similar industries with comparable supply chains. Therefore future research could expand the sample to include multiple grocery firms, or the generalisability of the findings could be tested by replicating the study in a different industry with similar supply chain characteristics. A further limitation of the study was that the study took the single-firm perspective on CPFR implementation, limiting the study in its supply chain network perspective. Subsequent research in the sector could include a dyadic view by gathering data from both the retailer and the manufacturer. Another limitation identified is that the study was confined to one industry in the South African market - the major grocery retail market. Given the outcomes of the study, further research should assess whether the key factors identified are the same across various sectors in South Africa. Furthermore, given that South Africa is a developing country, it might be beneficial to explore the collaborative demand and supply initiatives in retailers that are not included among the four major grocery retailers. 


\section{REFERENCES}

[1] Alftan, A., Kaipia, R., Loikkanen, L. \& Spens, K. 2015. Centralised grocery supply chain planning: Improved exception management, International Journal of Physical Distribution \& Logistics Management, 45(3), pp. 237-259.

[2] Domingo, T.M. 2013. The adoption of lean techniques to optimise the on-shelf availability of products and drive business performance in the food industry: A South African manufacturing and retail case study. Unpublished doctoral dissertation, University of Cape Town, Cape Town.

[3] Hollmann, R.L., Scavarda, L.F. \& Thomé, A.M.T. 2015. Collaborative planning, forecasting and replenishment: A literature review, International Journal of Productivity and Performance Management, 64(7), pp. 971-993.

[4] Vlckova, V. \& Patak, M. 2011. Barriers of demand planning implementation, Economics \& Management, $1(16)$, pp. 1000-1005.

[5] Lyu, J., Ding, J.H. \& Chen, P.S. 2010. Coordinating replenishment mechanisms in supply chain: From the collaborative supplier and store-level retailer perspective, International Journal of Production Economics, 123(1), pp. 221-234.

[6] Skjoett-Larsen, T., Thernøe, C. \& Andresen, C. 2003. Supply chain collaboration: Theoretical perspectives and empirical evidence, International Journal of Physical Distribution \& Logistics Management, 33(6), pp. 531-549.

[7] Audy, J.F., Lehoux, N., D’Amours, S. \& Rönnqvist, M. 2012. A framework for an efficient implementation of logistics collaborations, International Transactions in Operational Research, 19(5), pp. 633-657.

[8] De Paula, M., Oliveira, J., De Souza, J.M. \& Strauch, J. 2004. Improving design with collaborative planning, forecasting and replenishment through knowledge management, Computer Supported Cooperative Work in Design, 8(2), pp. 534-539.

[9] Smith, L. 2006. West Marine: A CPFR success story, Supply Chain Management Review, 10(2), pp. 29-36.

[10] Büyüközkan, G. \& Vardaloğlu, Z. 2012. Analyzing of CPFR success factors using fuzzy cognitive maps in retail industry, Expert Systems with Applications, 39(12), pp. 10438-10455.

[11] Panahifar, F., Heavey, C., Byrne, P.J. \& Asif Salam, M. 2015. Partner selection factors for successful CPFR implementation using fuzzy DEMATEL, Journal of Economics, Business and Management, 3(12), pp. 1138-1145.

[12] Cassivi, L. 2006. Collaboration planning in a supply chain, Supply Chain Management: An International Journal, 11(3), pp. 249-258.

[13] Kim, S.M. \& Mahoney, J.T. 2010. Collaborative planning, forecasting and replenishment (CPFR) as a relational contract: An incomplete contracting perspective, International Journal of Learning and Intellectual Capital, 7(3/4), pp. 403-428.

[14] Hernández, J.E., Mula, J., Poler, R. \& Lyons, A.C. 2014. Collaborative planning in multi-tier supply chains supported by a negotiation-based mechanism and multi-agent system, Group Decision and Negotiation, 23(2), pp. 235-269.

[15] Simatupang, T.M. \& Sridharan, R. 2005. An integrative framework for supply chain collaboration, The International Journal of Logistics Management, 16(2), pp. 257-274.

[16] VICS. 2004. Retailer event collaboration business process guide. Available at: www.vics.org/committees/cpfr/ [Accessed 10 March 2016].

[17] Forbes. 2013. Successful global growers: What we can learn from Walmart, Carrefour, Tesco, Metro. Available at: http://www.forbes.com/sites/walterloeb/2013/03/07/walmart-carrefour-tesco-metro successful-global-growers-what-can-we-learn-from-them/\#422f5b1c437f. [Accessed 15 May 2016].

[18] Småros, J. 2007. Forecasting collaboration in the European grocery sector: Observations from a case study, Journal of Operations Management, 25(3), pp. 702-716.

[19] Panahifar, F., Byrne, P.J. \& Heavey, C. 2014. ISM analysis of CPFR implementation barriers, International Journal of Production Research, 52(18), pp. 5255-5272.

[20] Fu, H.P., Chu, K.K., Lin, S.W. \& Chen, C.R. 2010. A study on factors for retailers implementing CPFR: A fuzzy AHP analysis, Journal of Systems Science and Systems Engineering, 19(2), pp. 192-209.

[21] Panahifar, F., Ghadimi, P., Azadnia, A.H., Heavey, C. \& Byrne, P.J. 2013. A study on CPFR implementation critical factors for the automotive spare part industry, Modelling and Simulation, 1(8), pp. 1-6.

[22] Pramatari, K. \& Miliotis, P. 2008. The impact of collaborative store ordering on shelf availability, Supply Chain Management: An International Journal, 13(1), pp. 49-61.

[23] Williams, B.D. \& Waller, M.A. 2011. Top-down versus bottom-up demand forecasts: The value of shared point-of-sale data in the retail supply chain, Journal of Business Logistics, 32(1), pp. 17-26.

[24] Lehoux, N., D’Amours, S. \& Langevin, A. 2014. Inter-firm collaborations and supply chain coordination: Review of key elements and case study, Production Planning \& Control, 25(10), pp. 858-872.

[25] Whipple, J.M. \& Russell, D. 2007. Building supply chain collaboration: A typology of collaborative approaches, The International Journal of Logistics Management, 18(2), pp. 174-196.

[26] Danese, P. 2011. Towards a contingency theory of collaborative planning initiatives in supply networks, International Journal of Production Research, 49(4), pp. 1081-1103.

[27] O'Sullivan, G. 2003. Industry-level collaboration through ECR, Journal of Supply Chain Management, 1(1), pp. 358-374. 
[28] Danese, P. 2006. How contextual factors shape CPFR collaborations: A theoretical framework, An international Journal, 7(2), pp. 15-26.

[29] Barratt, M. \& Oliveira, A. 2001. Exploring the experiences of collaborative planning initiatives, International Journal of Physical Distribution \& Logistics Management, 31(4), pp. 266-289.

[30] Walker, B., Bovet, D. \& Martha, J. 2000. Unlocking the supply chain to build competitive advantage, The International Journal of Logistics Management, 11(2), pp. 1-8.

[31] Bolin, S. 1998. E-commerce: A market analysis and prognostication, StandardView, 6(3), pp. 97-105.

[32] Treacy, M. \& Wiersema, F. 1993. Customer intimacy and other value disciplines, Harvard Business Review, 71(1), pp. 84-93.

[33] Chang, T.H., Fu, H.P., Lee, W.I., Lin, Y. \& Hsueh, H.C. 2007. A study of an augmented CPFR model for the 3C retail industry, Supply Chain Management: An International Journal, 12(3), pp. 200-209.

[34] Du, X.F., Leung, S.C.H., Zhang, J.L. \& Lai, K.K. 2009. Procurement of agricultural products using the CPFR approach, Supply Chain Management: An International Journal, 14(4), pp. 253-258.

[35] Fliedner, G. 2003. CPFR: An emerging supply chain tool, Industrial Management \& Data Systems, 109(1), pp. 14-21.

[36] Shu, T., Chen, S., Xie, C., Wang, S. \& Lai, K.K. 2010. Ave-CPFR working chains on the basis of selection model of collaborative credit-granting guarantee approaches, International Journal of Information Technology \& Decision Making, 9(2), pp. 301-325.

[37] Barrat, M. 2004. Understanding the meaning of collaboration in the supply chain, Supply Chain Management: An International Journal, 9(1), pp. 30-42.

[38] Attaran, M. 2012. Critical success factors and challenges of implementing RFID in supply chain management, Journal of Supply Chain and Operations Management, 10(1), pp. 144-167.

[39] Ghosh, A. \& Fedorowicz, J. 2008. The role of trust in supply chain governance, Business Process Management Journal, 14(4), pp. 453-470.

[40] Whipple, J.M., Frankel, R. \& Daugherty, P.J. 2002. Information support for alliances: Performance implications, Journal of Business Logistics, 23(2), pp. 67-82.

[41] Petersen, K.J., Ragatz, G.L. \& Monczka, R.M. 2005. An examination of collaborative planning effectiveness and supply chain performance, Journal of Supply Chain Management, 41(2), pp. 14-25.

[42] Attaran, M. 2004. Nurturing the supply chain, Industrial Management, 46(5), pp. 16-20.

[43] Creswell, J. 2007. Qualitative inquiry \& research design, $2^{\text {nd }}$ edition. Thousand Oaks, CA: Sage.

[44] Yin, R.K. 2009. Case study research: Design and methods, Essential guide to qualitative methods in organisational research, $4^{\text {th }}$ edition. Thousand Oaks, CA: Sage.

[45] Cooper, D.R. \& Schindler, P.S. 2014. Business research methods, $12^{\text {th }}$ edition. New York, NY: McGraw-Hill.

[46] Creswell, J.W. 2012. Education research: Planning, conducting and evaluating quantitative and qualitative research, $4^{\text {th }}$ edition. Boston, MA: Pearson.

[47] Plano Clarke, V. \& Creswell, J.W. 2015. Understanding research: A consumer's guide, $2^{\text {nd }}$ edition. Upper Saddle River, NJ: Pearson Education.

[48] Guest, G., Bunce, A. \& Johnson, L. 2006. How many interviews are enough? An experiment with data saturation and variability, Field Methods, 18(1), pp. 59-82.

[49] Rowley, J. 2012. Conducting research interviews, Management Research Review, 35(3/4), pp. 260-271.

[50] Eisenhardt, K.M. 1989. Making fast strategic decisions in high-velocity environments, Academy of Management Journal, 32(3), pp. 543-576.

[51] Creswell, J. \& Miller, D. 2000. Determining validity in qualitative inquiry, Theory into Practice, 39(3), pp. 124-130.

[52] Farquhar, J.D. 2012. Case study research for business. London: Sage.

[53] Braun, V. \& Clarke, V. 2012. Thematic analysis. In: Cooper, H. (ed.), APA handbook of research methods in psychology: Volume 2: Research designs. Washington, DC: American Psychological Association.

[54] Shenton, A. 2004. Strategies for ensuring trustworthiness in qualitative research projects, Education for Information, 22(2), pp. 63-75.

[55] Polit, D.F. \& Beck, C.T. 2012. Nursing research: Generating and assessing evidence for nursing practice, $9^{\text {th }}$ edition. Philadelphia: Lippincott Williams \& Wilkins.

[56] Piderit, R., Flowerday, S. \& Von Solms, R. 2011. Enabling information sharing by establishing trust in supply chains: A case study in the South African automotive industry: Original research, South African Journal of Information Management, 13(1), pp. 1-8.

[57] White, R. 2014. Probing understanding. New York, NY: Routledge.

[58] Aguilar-Saven, R.S. 2004. Business process modelling: Review and framework, International Journal of Production Economics, 90(2), pp. 129-149.

[59] Emberson, C. \& Storey, J. 2006. Buyer-supplier collaborative relationships: Beyond the normative accounts, Journal of Purchasing and Supply Management, 12(5), pp. 236-245.

[60] Morgan, R.M. \& Hunt, S.D. 1994. The commitment-trust theory of relationship marketing, The Journal of Marketing, 58(3), pp. 20-38.

[61] Fawcett, S.E., Jones, S.L. \& Fawcett, A.M. 2012. Supply chain trust: The catalyst for collaborative innovation, Business Horizons, 55(2):163-178.

[62] Spekman, R.E. \& Carraway, R. 2006. Making the transition to collaborative buyer-seller relationships: An emerging framework, Industrial Marketing Management, 35(1):10-19. 